\title{
In vitro evaluation of total mixed ration supplemented with exogenous fibrolytic enzymes for crossbred cows
}

\author{
Pravin Mohan Lunagariya ${ }^{1}$, Ram Sharan Gupta² and Subhash Parnerkar ${ }^{2}$
}

1. Livestock Research Station, College of Veterinary Science and Animal Husbandry, Anand Agricultural University, Anand, Gujarat, India; 2. Department of Animal Nutrition Research, College of veterinary Science and Animal Husbandry, Anand Agricultural University, Anand, Gujarat, India.

Corresponding author: Pravin Mohan Lunagariya, e-mail: drpravinml@gmail.com, Co-authors: RSG: gupta.ramsharan@gmail.com, SP: parnerkar13@gmail.com

Received: 18-10-2016, Accepted: 31-01-2017, Published online: 05-03-2017

doi: 10.14202/vetworld.2017.281-285 How to cite this article: Lunagariya PM, Gupta RS, Parnerkar S (2017) In vitro evaluation of total mixed ration supplemented with exogenous fibrolytic enzymes for crossbred cows, Veterinary World, 10(3): 281-285.

\begin{abstract}
Aim: The study was conducted to evaluate the levels of exogenous fibrolytic enzymes (EFE) on in vitro digestibilities of dry matter (DM) and organic matter (OM), total gas production (TGP), metabolizable energy (ME) content, and microbial biomass production (MBP).

Materials and Methods: The total mixed ration (TMR) was prepared using $30 \%$ each of sorghum hay and groundnut straw and $40 \%$ compound concentrate mixture to meet nutritional requirement of cow $(500 \mathrm{~kg})$ producing $12 \mathrm{~kg}$ fat corrected milk. The EFE was incorporated at 0, 40, 60, 80, 100, 120, 140, 160, 180, 200, 220, 240, 260, 280, 300, 320, 340, 360, 380, and $400 \mathrm{mg} / \mathrm{kg}$ TMR. The TMR substrates with different levels of EFE were in vitro incubated to ascertain their effect on digestibility, gas production, and nutritive values.

Results: The significantly $(\mathrm{p}<0.05)$ higher and optimum in vitro digestibilities of DM $(63.03 \%)$ and OM $(63.62 \%)$ as well as TGP (72.35 ml/500 mg TMR) were observed at supplementation of $240 \mathrm{mg}$ EFE/ $/ \mathrm{kg}$ TMR, while ME (7.16 MJ $/ \mathrm{kg} \mathrm{DM})$ and MBP $(97.63 \mathrm{mg} / 500 \mathrm{mg}$ TMR) were also better.

Conclusion: The incorporation of EFE at $240 \mathrm{mg} / \mathrm{kg}$ TMR resulted significantly $(\mathrm{p}<0.05)$ higher and optimum in vitro digestibilities of DM and OM. The TGP, ME, and MBP were also better. The levels of EFE $240 \mathrm{mg} / \mathrm{kg}$ TMR were found suitable for further in vivo study in crossbred cows.
\end{abstract}

Keywords: exogenous fibrolytic enzymes, in vitro digestibility, metabolizable energy, microbial biomass production, total gas production.

\section{Introduction}

In India, ruminant feeding relies mainly on agro-industrial byproduct and crop residues. These feeds are low in energy and protein owing to high fiber, lignin and silica. Ruminant animals have the ability to convert low quality feeds into high quality protein due to ruminal microorganisms that synthesize and secrete $\beta$ 1-4 cellulase enzyme complex, thereby allowing hydrolysis of plant cell wall components. However, the actual conversion of feeds, especially fibrous forages to meat and milk, is not very efficient. Only $10-35 \%$ of energy intake is captured as net energy because $20-70 \%$ of cellulose may not be digested by the animal [1].

The supplementation of exogenous fibrolytic enzymes (EFE) in feeds has been identified as a promising biological treatment to improve the energy availability of feeds to ruminants. Positive effects of EFE

Copyright: Lunagariya, et al. Open Access. This article is distributed under the terms of the Creative Commons Attribution 4.0 International License (http://creativecommons.org/licenses/ by/4.0/), which permits unrestricted use, distribution, and reproduction in any medium, provided you give appropriate credit to the original author(s) and the source, provide a link to the Creative Commons license, and indicate if changes were made. The Creative Commons Public Domain Dedication waiver (http:// creativecommons.org/publicdomain/zero/1.0/) applies to the data made available in this article, unless otherwise stated. include direct hydrolysis, improvement in palatability, changes in gut viscosity, complimentary action with ruminal enzymes, change in the site of digestion [2], increase in rumen bacterial colonization of the substrate [3], altering fiber cell wall structures, and thinning of fiber cell wall [4]. The feeding of diets supplemented with EFE were shown to improve the digestibilities of dry matter $(\mathrm{DM})$, organic matter $(\mathrm{OM})$, crude fiber, neutral detergent fiber (NDF), cellulose and hemicellulose in dairy animals [5-7]. An in vivo investigation need living animals which is expensive as well as time consuming. An in vitro study conducted outside living animals to evaluate the effect of EFE in improving ration digestibility as they are less expensive, less time consuming and allows more control [8].

It was hypothesized that EFE improve the fermentation kinetics. The study was planned to assess the effect of supplementing various levels of EFE in TMR on in vitro digestibility, total gas production (TGP), metabolizable energy (ME) content, and microbial biomass production (MBP).

\section{Materials and Methods}

Ethical approval

An ethical approval was obtained from the Institutional Animal Ethics Committee of College of 
Veterinary Science and Animal Husbandry, Anand Agricultural University, Anand for this study. The study was conducted at Animal Nutrition Research Department, College of Veterinary Science and A. H., Anand Agricultural University, Anand.

Sample preparation, in vitro incubation and analysis

Sorghum hay, groundnut straw and compound concentrate mixture were procured from Animal Nutrition Research Department, College of Veterinary Science and Animal Husbandry, Anand Agricultural University, Anand. These ingredients were oven dried at $70^{\circ} \mathrm{C}$ and finely ground in mill using $1 \mathrm{~mm}$ sieve. These ingredients were mixed in ratios of $30 \%, 30 \%$ and $40 \%$ to prepare total mixed ration (TMR). The TMR was prepared to meet nutritional requirement of dairy cow $(500 \mathrm{~kg}$ ) producing $12 \mathrm{~kg} \mathrm{4 \%}$ fat corrected milk (FCM) per day [9]. The calculated nutritional values of TMR were $10.61 \%$ crude protein (CP), $6.59 \%$ digestible CP (DCP), $56.51 \%$ total digestible nutrients, and $2.05 \mathrm{Mcal} \mathrm{ME} / \mathrm{kg} \mathrm{DM}$. The ingredients and TMR were analyzed for proximate constituents [10], fiber fractions [11] and calcium and phosphorus.

The EFE was procured from M/s DSM Nutritional Products India Pvt. Ltd., Thane, India. It contained endo 1,4- $\beta$ glucanase $800,1(3), 4-\beta$ glucanase 700 and endo 1,4- $\beta$ xylanase $2700 \mathrm{IU} / \mathrm{g}$. The EFE was incorporated at $0,40,60,80,100,120,140,160$, $180,200,220,240,260,280,300,320,340,360,380$, and $400 \mathrm{mg} / \mathrm{kg}$ TMR to know their effect on in vitro digestibility of $\mathrm{DM}$ and $\mathrm{OM}$, in vitro TGP, $\mathrm{ME}$ content and MBP. The level of EFE used was designated as $\mathrm{E}_{0}$, $\mathrm{E}_{4}, \mathrm{E}_{6}, \mathrm{E}_{8}, \mathrm{E}_{10}, \mathrm{E}_{12}, \mathrm{E}_{14}, \mathrm{E}_{16}, \mathrm{E}_{18}, \mathrm{E}_{20}, \mathrm{E}_{22}, \mathrm{E}_{24}, \mathrm{E}_{26}, \mathrm{E}_{28}$, $\mathrm{E}_{30}, \mathrm{E}_{32}, \mathrm{E}_{34}, \mathrm{E}_{36}, \mathrm{E}_{38}$ and $\mathrm{E}_{40}$, respectively.

Rumen liquor was collected from three crossbred cows using stomach tube. The cows were fed individually to meet nutrients requirement [9] with free water access. The rumen liquor was strained through four layer muslin cloth and was termed strained rumen liquor (SRL). TMR with various levels of EFE were incubated for $48 \mathrm{~h}$ in quadruplet at $39 \pm 1^{\circ} \mathrm{C}$ for $48 \mathrm{~h}$ in a shaker twin water bath with $40 \mathrm{ml}$ of fresh McDougall buffer and $10 \mathrm{ml} \mathrm{SRL}$ as per Menke et al. [12]. After incubation, the content of each syringe was filtered through dried and pre-weighed Gooch crucible, which was again dried and weighed. Simultaneously, the blank was also run without TMR sample in quadruplet. The in vitro TGP was taken after subtracting gas production from blank. The ME [13] and MBP [14] were calculated as:

$$
\mathrm{ME}(\mathrm{MJ} / \mathrm{kg} \mathrm{DM})=2.20+0.136 \mathrm{Gp}+0.057 \mathrm{CP} \% \text {, }
$$$$
\left(\mathrm{R}^{2}=0.94\right)
$$

Where, $\mathrm{CP}$ is crude protein $\%$ and $\mathrm{Gp}$ is $\mathrm{ml}$ of net gas production from $200 \mathrm{mg}$ dry sample.

$\mathrm{MBP}=\{\mathrm{TDOM}-(2.2 \times$ net gas volume $)\}$; $\mathrm{TDOM}=($ Feed $\mathrm{OM}$ incubated-residue $\mathrm{OM})$.

Where, TDOM is total digestible OM.

\section{Statistical analysis}

The data on digestibility, TGP, ME and MBP were analyzed [15] using Duncan's multiple range tests (SPSS 9.00 software).

\section{Results and Discussion}

The data for proximate composition and fiber fractions of ingredients and TMR used are presented in Table-1. The TMR contained $10.24 \%$ CP, $55.06 \%$ NDF, and $28.82 \%$ ADF. The data for in vitro digestibility (\%) of DM and OM, TGP, ME content and MBP of TMR incorporated with various levels of EFE are presented in Table-2.

\section{In vitro DM digestibility (IVDMD)}

The data revealed significant $(p<0.05)$ effect of level of incorporation of EFE at and beyond $120 \mathrm{mg} / \mathrm{kg}$ TMR $(56.54 \pm 0.58 \%)$ in comparison to control TMR $(54.36 \pm 0.45 \%)$ without EFE. However, incorporation level of EFE at $240 \mathrm{mg} / \mathrm{kg}$ TMR had improved $(p<0.05)$ DM digestibility $(60.36 \pm 0.39 \%)$ than lower levels of incorporation. Further increase in level of fibrolytic enzyme did not show beneficial effect on IVDMD.

Incorporation of EFE at $2.5 \mathrm{~g} / \mathrm{kg}$ DM TMR (roughage to concentrate ratio of 60:40) resulted in similar observations and significantly higher $62.18 \%$ $(p \leq 0.001)$ IVDMD than control TMR $(58.44 \%)$ [16]. Miachieo and Thakur [5] reported optimum and higher IVDMD of TMR having concentrate, wheat straw and green oats in ratios of $40: 40: 20$ as $55.0 \%$ when incorporated with fibrolytic enzymes at $1.5 \mathrm{~g} / \mathrm{kg}$

Table-1: Average proximate composition and fiber fractions (\% on DM basis) of feeds and fodder.

\begin{tabular}{lcccr}
\hline Parameters & TMR & Concentrate mixture & Sorghum hay & Groundnut straw \\
\hline CP & $10.24 \pm 0.22$ & 14.18 & 5.72 & 9.02 \\
EE & $3.36 \pm 0.05$ & 6.27 & 1.72 & 1.05 \\
CF & $21.79 \pm 0.40$ & 9.96 & 35.18 & 28.98 \\
NFE & $53.52 \pm 0.24$ & 59.79 & 47.92 & 50.05 \\
Total ash & $11.09 \pm 0.10$ & 9.80 & 9.46 & 10.90 \\
Silica & $3.10 \pm 0.44$ & 1.08 & 3.24 & 2.07 \\
Calcium & $1.24 \pm 0.36$ & 1.31 & 0.70 & 0.91 \\
Phosphorus & $0.48 \pm 0.01$ & 0.65 & 0.27 & 0.36 \\
NDF & $55.06 \pm 0.87$ & 26.48 & 72.52 & 69.91 \\
ADF & $28.82 \pm 0.27$ & 11.19 & 48.16 & 36.61 \\
\hline
\end{tabular}

$\mathrm{DM}=$ Dry matter, $\mathrm{TMR}=$ Total mixed ration, $\mathrm{CP}=$ Crude protein, NDF=Neutral detergent fiber, $\mathrm{ADF}=$ Acid detergent fiber, $\mathrm{NFE}=$ Nitrogen-free extract, $\mathrm{CF}=$ Crude fiber, $\mathrm{EE}=\mathrm{Ether}$ extract 
Table-2: Average IVDMD, IVOMD, IVTGP, ME and MBP of TMR containing different levels of exogenous fibrolytic enzymes.

\begin{tabular}{|c|c|c|c|c|c|}
\hline \multirow[t]{2}{*}{ TMR } & \multicolumn{5}{|c|}{ Particulars } \\
\hline & IVDMD (\%) & IVOMD (\%) & IVTGP (ml) & ME (MJ/kg DM) & MBP (mg/500 mg TMR) \\
\hline$E_{0}$ & $54.36^{a} \pm 0.45$ & $55.44^{\mathrm{a}} \pm 0.36$ & $61.30^{\mathrm{a}} \pm 1.05$ & $6.49^{a} \pm 0.06$ & $87.37^{a} \pm 1.37$ \\
\hline $\mathrm{E}_{4}$ & $54.65^{\mathrm{a}} \pm 0.62$ & $55.63^{\mathrm{a}} \pm 0.58$ & $61.40^{\mathrm{a}} \pm 1.17$ & $6.49^{a} \pm 0.07$ & $87.18^{\mathrm{a}} \pm 0.72$ \\
\hline $\mathrm{E}_{6}$ & $54.82^{\mathrm{ab}} \pm 0.78$ & $56.26^{\mathrm{ab}} \pm 0.59$ & $62.00^{\mathrm{a}} \pm 1.23$ & $6.53^{\mathrm{ab}} \pm 0.07$ & $88.89^{\mathrm{a}} \pm 0.75$ \\
\hline $\mathrm{E}_{8}$ & $55.36^{\mathrm{ab}} \pm 0.25$ & $55.94^{a} \pm 0.27$ & $62.73^{\mathrm{ab}} \pm 1.45$ & $6.58^{\mathrm{ab}} \pm 0.09$ & $87.16^{\mathrm{a}} \pm 1.79$ \\
\hline$E_{10}$ & $55.54^{\mathrm{ab}} \pm 0.45$ & $56.86^{\mathrm{ab}} \pm 0.43$ & $64.03^{\mathrm{abc}} \pm 0.84$ & $6.65^{b c} \pm 0.05$ & $87.26^{a} \pm 0.56$ \\
\hline $\mathrm{E}_{12}$ & $56.54^{b} \pm 0.58$ & $57.76^{\mathrm{bc}} \pm 0.49$ & $65.60^{\mathrm{bcd}} \pm 0.56$ & $6.75^{\mathrm{cd}} \pm 0.03$ & $87.56^{\mathrm{a}} \pm 0.82$ \\
\hline$E_{14}^{12}$ & $56.67^{b} \pm 0.64$ & $58.65^{\ulcorner} \pm 0.58$ & $65.88^{\mathrm{bcd}} \pm 0.46$ & $6.77^{\mathrm{cd}} \pm 0.03$ & $89.72^{\mathrm{ab}} \pm 1.50$ \\
\hline $\mathrm{E}_{16}^{14}$ & $58.43^{c} \pm 0.20$ & $59.18^{c} \pm 0.12$ & $67.18^{\text {cde }} \pm 0.64$ & $6.84^{\mathrm{de}} \pm 0.04$ & $89.08^{\mathrm{a}} \pm 1.50$ \\
\hline$E_{18}^{10}$ & $59.46^{\mathrm{cd}} \pm 0.31$ & $60.96^{d} \pm 0.11$ & $68.45^{\mathrm{def}} \pm 0.45$ & $6.92^{\mathrm{ef}} \pm 0.03$ & $93.27^{b c} \pm 0.86$ \\
\hline $\mathrm{E}_{20}^{18}$ & $60.36^{\mathrm{de}} \pm 0.40$ & $62.28^{\mathrm{de}} \pm 0.29$ & $70.08^{\mathrm{efg}} \pm 0.29$ & $7.02^{\mathrm{fg}} \pm 0.02$ & $95.96^{\mathrm{cd}} \pm 0.39$ \\
\hline $\mathrm{E}_{22}$ & $62.05^{e} \pm 0.36$ & $63.62^{\mathrm{ef}} \pm 0.44$ & $70.85^{f g} \pm 0.61$ & $7.07^{g} \pm 0.02$ & $100.71^{f} \pm 1.36$ \\
\hline $\mathrm{E}_{24}^{22}$ & $63.03^{\mathrm{ef}} \pm 0.39$ & $63.96^{f} \pm 0.24$ & $72.35^{9} \pm 0.56$ & $7.16^{9} \pm 0.03$ & $97.63^{\mathrm{def}} \pm 1.00$ \\
\hline$E_{26}^{24}$ & $63.21^{f} \pm 0.39$ & $63.90^{\mathrm{ef}} \pm 0.13$ & $72.33^{9} \pm 0.66$ & $7.16^{9} \pm 0.04$ & $96.29^{\text {cde }} \pm 1.22$ \\
\hline$E_{28}^{20}$ & $63.12^{f} \pm 0.22$ & $64.68^{f} \pm 0.07$ & $72.28^{9} \pm 0.28$ & $7.15^{9} \pm 0.02$ & $100.42^{\mathrm{ef}} \pm 0.82$ \\
\hline$E_{30}^{20}$ & $63.74^{f} \pm 0.57$ & $64.44^{f} \pm 0.63$ & $72.78^{9} \pm 0.82$ & $7.18^{9} \pm 0.05$ & $99.12^{\mathrm{def}} \pm 1.24$ \\
\hline$E_{32}$ & $63.55^{f} \pm 0.50$ & $64.28^{f} \pm 0.67$ & $72.20^{9} \pm 0.67$ & $7.15^{g} \pm 0.04$ & $98.60^{\mathrm{def}} \pm 1.98$ \\
\hline$E_{34}$ & $63.56^{f} \pm 0.46$ & $64.54^{f} \pm 0.48$ & $72.50^{9} \pm 0.67$ & $7.17^{g} \pm 0.04$ & $99.49^{\mathrm{def}} \pm 1.09$ \\
\hline $\mathrm{E}_{36}$ & $63.59^{f} \pm 0.31$ & $64.78^{f} \pm 0.51$ & $72.35^{9} \pm 0.81$ & $7.16^{9} \pm 0.05$ & $101.14^{\mathrm{f}} \pm 2.47$ \\
\hline $\mathrm{E}_{38}$ & $63.20^{f} \pm 0.42$ & $64.61^{f} \pm 0.20$ & $72.00^{\circ} \pm 0.50$ & $7.14^{9} \pm 0.03$ & $100.74^{f} \pm 1.19$ \\
\hline$E_{40}^{30}$ & $63.75^{f} \pm 0.16$ & $64.89^{f} \pm 0.20$ & $72.25^{9} \pm 0.87$ & $7.15^{9} \pm 0.03$ & $100.53^{f} \pm 1.40$ \\
\hline SEM & 0.41 & 0.41 & 0.50 & 0.03 & 0.67 \\
\hline
\end{tabular}

$a, b, c, d, e, f, g$ Means with different superscripts in a column for a parameter differ significantly $(p<0.05)$. DM=Dry matter, $\mathrm{TMR}=$ Total mixed ration, $\mathrm{MBP}=$ Microbial biomass production, $\mathrm{ME}=$ Metabolizable energy, IVTGP $=$ In vitro total gas production, IVOMD=In vitro organic matter digestibility, IVDMD=In vitro dry matter digestibility

DM than control TMR without EFE or TMR with higher $(3.0 \mathrm{~g} / \mathrm{kg}$ DM) EFE. These findings were in accordance with this study. Similarly, significantly higher IVDMD was also observed [17-19] when TMR was supplemented with fibrolytic enzyme. However, the effect of incubation of corn silage based diet with exogenous enzyme at 1.68 and $2.52 \mathrm{~g} / \mathrm{kg}$ was nonsignificant on apparent DM degradability [20] as silage is considered as pre-digested forage (corn silage).

\section{In vitro OM digestibility (IVOMD)}

The data of IVOMD revealed significant $(p<0.05)$ effect of level of incorporation of EFE at and beyond $120 \mathrm{mg} / \mathrm{kg}$ TMR $(57.76 \pm 0.49 \%)$ in comparison to control $(55.44 \pm 0.36 \%)$, but optimum and significantly higher values were observed $(63.96 \pm 0.24 \%)$ when EFE incorporated at $240 \mathrm{mg} / \mathrm{kg}$ TMR and further increase in level of EFE had no beneficial effect.

The quadratic improvement $(\mathrm{p}=0.004)$ of in vitro OM degradability was observed as $0.336,0.365$, 0.387 and $0.426 \mathrm{~g} / \mathrm{g} \mathrm{DM}$, respectively, when sorghum straw was incubated with $0,6,12$ and $24 \mathrm{mg}$ enzyme/g DM [21]. The optimum IVOMD $(\mathrm{p}<0.05)$ reported was $56.1 \%$ for TMR incorporated with EFE at $1.5 \mathrm{~g} / \mathrm{kg}$ DM than for control or higher levels of EFE (3.0 g/kg DM) in TMR [5]. The findings of these studies were in agreement with present experiment. Similarly, in-vitro OM disappearance of alfalfa hay $(46.21 \%)$ was optimum $(p<0.01)$ when fibrolytic enzyme was added at $2 \mu 1 / \mathrm{g}$ DM compared with alfalfa hay $(44.9 \%)$ incubated without EFE. Intermediate effect was observed for alfalfa hay incubated with 0.5, 1.0 and $1.5 \mu \mathrm{EFE} / \mathrm{g}$ DM, but OM disappearance was not improved when alfalfa silage and barley silage were used [22] being pre-digested fodder. An improvement in OM degradability was also reported on supplementation of fibrolytic bacterial culture in wheat straw DM [23] and fibrolytic enzymes in TMR [13] than control.

\section{In vitro TGP (IVTGP)}

There was a significant difference in gas production for control $(61.30 \pm 1.05 \mathrm{ml})$ and experimental TMRs incorporated with EFE at $120 \mathrm{mg} / \mathrm{kg}$ TMR $(65.60 \pm 0.56 \mathrm{ml})$ and higher levels. However, incorporation of EFE at $240 \mathrm{mg} / \mathrm{kg}$ TMR had shown significant $(p<0.05)$ effect on IVTGP, and further incorporation of higher levels of EFE in TMR had not shown further improvement in TGP.

The higher $(\mathrm{p} \leq 0.05)$ in vitro gas production observed as $96.33 \mathrm{ml}$ and $96.00 \mathrm{ml}$ when dry sorghum supplemented with EFE (1:1 mixture of neutral cellulase-3000 units/g and fungal xylanase- 200000 units/g) at 0.6 and $0.8 \%$, respectively, than dry sorghum supplemented without or with lower levels of fibrolytic enzymes $(0,0.01,0.1,0.2,0.3$, and $0.5 \%)$. Supplementation of higher levels $(0.9 \%$ and $1 \%)$ of fibrolytic enzymes had no further beneficial effect on in vitro gas production [24]. Similarly, significant effect of EFE supplementation in roughage diet [18], maize stover and sugarcane bagasse [25], and sorghum straw [21] was observed for in vitro gas production.

Aninvitrogasproduction(137.14-230.97ml/gDM) at 48 hours of incubation had shown no incremental effect when five TMR of different maize silage (F) to concentrate $(\mathrm{C})$ ratio $(0 \mathrm{~F}: 100 \mathrm{C}, 25 \mathrm{~F}: 75 \mathrm{C}, 50 \mathrm{~F}: 50 \mathrm{C}$, 
75F:25C, 100F:0C) supplemented with EFE, viz., cellulase $1 \mu \mathrm{l} / \mathrm{g}(\mathrm{C}, 0.033 \mathrm{unit} / \mathrm{g})$, xylanase $1 \mu \mathrm{l} / \mathrm{g}(\mathrm{X}$, $0.038 \mathrm{unit} / \mathrm{g}$ ), a mixture of cellulase, and xylanase (XC, $1: 1, \mathrm{v}: \mathrm{v})$ was used [13] this may be due to utilization of pre-digested forage (maize silage).

\section{ME content of feed}

The ME content of TMR ranges from 6.49 to $7.18 \mathrm{MJ} / \mathrm{kg} \mathrm{DM}$. However, ME of TMR $(6.65 \pm 0.05 \mathrm{MJ} / \mathrm{kg} \mathrm{DM})$ significantly improved at EFE level $100 \mathrm{mg} / \mathrm{kg}$ than control but optimum and significantly higher ME content of TMR was $7.16 \pm 0.03 \mathrm{MJ} / \mathrm{kg}$ DM when TMR was incorporated with EFE $240 \mathrm{mg} / \mathrm{kg}$. Further higher level of incorporation of EFE had shown no improvement in ME content of TMR. The ME content of TMR was lower than calculated ME $(9.50 \mathrm{MJ} / \mathrm{kg}$ $\mathrm{DM})$, but ME content of TMR increased as there was increase in level of incorporation of EFE.

The ME content of sorghum straw increased $(p<0.05)$ quadratic and values were 5.0, 5.4, 5.7 and $6.3 \mathrm{MJ} / \mathrm{kg} \mathrm{DM}$, respectively, when incubated with exogenous enzymes mixture at $0,6,12$ and $24 \mathrm{mg} / \mathrm{g}$ DM [21] levels. The TMR having 50\% maize silage (F) and 50\% concentrate when incubated with cellulase $1 \mu \mathrm{l} / \mathrm{g}(\mathrm{C}, 0.033 \mathrm{unit} / \mathrm{g})$, xylanase $1 \mu \mathrm{l} / \mathrm{g}$ (X, 0.038 unit/g), a mixture of cellulase and xylanase (XC, 1:1, $\mathrm{v}: \mathrm{v})$ and without EFE resulted in similar and nonsignificant ( $\mathrm{p}=0.0734$ ) ME content of TMR as 6.89, 6.76, 7.12 and $6.88 \mathrm{MJ} / \mathrm{kg} \mathrm{DM}$, respectively [13].

\section{MBP}

The MBP (mg/500 mg TMR) increased linearly with increasing levels of EFE in TMR, however, significantly higher MBP was achieved at $180 \mathrm{mg}$ EFE/kg TMR (93.27 \pm 0.86$)$. The optimum and significantly higher MBP as $97.63 \pm 1.00$ and $100.71 \pm 1.36 \mathrm{mg} / 500 \mathrm{mg}$ TMR was achieved at 240 and $220 \mathrm{mg}$ EFE/kg TMR, respectively, than control or lower levels. The further higher levels of incorporation of EFE did not show improvement in MBP.

Higher level of MBP (72.21-90.69 mg/200 mg) was achieved when $0.00-30.00 \%$ walnut (Juglans regia) cake was incorporated in concentrate to form iso-nitrogenous TMR [14]. The MBP values reported in this study are within the normal range (100$470 \mathrm{~g} / \mathrm{kg}$ TDOM) for mixed diets [26]. Nonsignificant $(\mathrm{p}=0.6602)$ difference in MBP was observed (513.2, $520.3,496.2$ and $521.0 \mathrm{mg} / \mathrm{g} \mathrm{DM}$, respectively) when TMR with $50 \%$ maize silage (F) and $50 \%$ concentrate was incubated with EFE, viz., cellulase $1 \mu \mathrm{l} / \mathrm{g}$ (C, 0.033 unit/g), xylanase $1 \mu \mathrm{l} / \mathrm{g}(\mathrm{X}, 0.038$ unit/g), a mixture of cellulase and xylanase (XC, 1:1, v:v), and control TMR [13].

In vitro digestibility of $\mathrm{DM}$ and $\mathrm{OM}$ and IVTGP was found to be optimum $(\mathrm{p}<0.05)$, respectively, as $63.03 \pm 0.39 \%, 63.96 \pm 0.44 \%$ and $70.85 \pm 0.61 \mathrm{ml} / 500 \mathrm{mg}$ of TMR when incorporated with EFE at $240 \mathrm{mg} / \mathrm{kg}$ TMR than control TMR, or other levels of EFE. The optimum and higher ME $(7.16 \pm 0.03 \mathrm{MJ} / \mathrm{kg} \mathrm{DM})$ and $\mathrm{MBP}$
$(97.63 \pm 1.00 \mathrm{mg} / 500 \mathrm{mg}$ TMR) was achieved at EFE $240 \mathrm{mg} / \mathrm{kg}$ TMR in comparison to TMR without EFE. Positive and linear increase in TGP was observed with improvement in digestibility of DM and OM. The same correlation of gas production with digestibility of DM and OM under in vitro study were also observed [27,14]. An improved digestibility, gas production, ME and MBP may be due to action of EFE to degrade complex fraction to simple molecules making them more available to rumen microbes [28], synergetic effect of EFE and rumen microbe [29], enhance attachment of rumen microbial to feed particles [30], and stimulatory effect on rumen microbiota [31].

\section{Conclusion}

An in vitro digestibility of DM (56.54\%), OM (57.76\%), and TGP (65.60 ml/500 mg TMR) was significantly $(\mathrm{p}<0.05)$ higher when EFE was supplemented at $120 \mathrm{mg} / \mathrm{kg}$ TMR in comparison to control, whereas ME (6.65 MJ/kg DM) and MBP (93.27 mg/500 mg TMR) were significant at 100 and $180 \mathrm{mg} / \mathrm{kg}$ TMR, respectively. The incorporation of EFE at $240 \mathrm{mg} / \mathrm{kg}$ in TMR resulted in significantly $(p<0.05)$ higher and optimum in vitro digestibilities of DM (63.03\%) and OM (63.96\%) compared to lower levels. TGP (72.35 ml/500 mg TMR), ME (7.16 MJ/kg DM), and MBP (97.63 mg/500 mg TMR) were also better. The digestibility, gas production and nutritive values of TMR did not show improvement with higher supplementation of EFE. The levels of EFE $240 \mathrm{mg} / \mathrm{kg}$ TMR were found suitable for further in vivo study in crossbred cows.

\section{Authors' Contributions}

RSG and SP: Conceptualized, designed and supervised the study. PML: Designed, executed study, carried out laboratory analysis and drafted and revised the manuscript. All authors have read and approved the final manuscript.

\section{Acknowledgments}

The authors acknowledge facilities and financial support provided by Authority of Anand Agricultural University, Anand for this study. The authors also acknowledge provision of exogenous fibrolytic enzyme by M/s. DSM Nutritional Products India Pvt. Ltd., Thane, India, free of cost. The help rendered by Mr. Hiren Pansuriya and Kashmira Khaire for laboratory analysis and Dr. DC Patel for solving the trouble associated with analysis is gratefully acknowledged.

\section{Competing Interests}

The authors declare that they have no competing interests.

\section{References}

1. Varga, G.A. and Kolver, E.S. (1997) Microbial and animal limitations to fiber digestion and utilization. J. Nutr., 127: 819-824.

2. Beauchemin, K.A. and Rode, L.M. (1996) Use of Feed 
Enzymes in Ruminant Nutrition. Proceedings in Canadian Society of Animal Science. Annual Meeting, Lethbridge, Alberta. p103-140.

3. Wang, Y., Ramirez-Bribiesca, J.E., Yanke, L.J., Tsang, A. and McAllister, T.A. (2012) Effect of exogenous fibrolytic enzyme application on the microbial attachment and digestion of barley straw in vitro. Asian Australas. J. Anim., 25(1): 66-74.

4. van de Vyver, W.F.J. and Cruywagen, C.W.C. (2013) Exogenous fibrolytic enzymes to unlock nutrients: Histological investigation of its effects on fibre degradation in ruminants. S. Afr. J. Anim. Sci., 43(5): S54-S59.

5. Miachieo, K. and Thakur, S.S. (2007) Effect of exogenous fibrolytic enzymes on the productive performance of lactating Sahiwal cows. Indian J. Anim. Nutr., 24(1): 27-30.

6. Rajamma, K., Kumar, D.S., Rao, E.R. and Nath, D.N. (2014) Nutrient utilization in buffalo bulls fed total mixed rations supplemented with exogenous fibrolytic enzymes. Indian J. Anim. Nutr., 31(3): 213-217.

7. Morsy, T.A., Kholif, A.E., Kholif, S.M., Kholif, A.M., Sun, X. and Salem, A.Z.M. (2015) Effects of two enzyme feed additives on digestion and milk production in lactating Egyptian buffaloes. Ann. Anim. Sci., 16(1): 209-222.

8. Makkar, H.P.S. (2004) Recent advances in the in vitro gas method for evaluation of nutritional quality of feed resources. In: Assessing Quality and Safety of Animal Feeds. Food and Agriculture Organization of United Nations, Rome. p55-88. Available from: http://www.fao.org/docrep/007/y5159e/ y5159e05.htm. Downloaded on 28-4-2016.

9. NRC. (2001) Nutrient Requirements of Dairy Cattle. $7^{\text {th }}$ Revised Edition. Subcommittee on Dairy Cattle Nutrition, Committee on Animal Nutrition, National Research Council, National Academy Press, Washington, DC. Available from: http://www.nap.edu/catalog/9825.htm. Accessed on 25-08-2016.

10. AOAC. (1995) Official Methods of Analysis. $16^{\text {th }}$ ed. Association of Official Analytical Chemists, Washington, DC.

11. Van Soest, P.J., Robertson, J.B. and Lewis, B.A. (1991) Methods of dietary fiber, neutral detergent fiber and non starch polysaccharides in relation to animal nutrition. J. Dairy Sci., 74: 3583-3597.

12. Menke, K.H., Rabb, L., Salewski, A., Steingass, H., Fritz, D. and Schneiser, W. (1979) The estimation of the digestibility and metabolizable energy content of ruminant feedstuffs from the gas production when they are incubated with rumen liquor in vitro. J. Agric. Sci., 93: 217-222.

13. Elghandour, M.M.M., Kholif, A.E., Márquez-Molina, O., Vázquez-Armijo, J.S., Puniya, A.K. and Salem, A.Z.M. (2015) Influence of individual or mixed cellulase and xylanase mixtures on in vitro rumen gas production kinetics of total mixed rations with different maize silage and concentrate ratios. Turk. J. Vet. Anim. Sci., 39: 1-8.

14. Mir, M.A., Sharma, R.K., Rastogi, A. and Barman, K. (2015) Effect of incorporation of walnut cake (Juglans regia) in concentrate mixture on degradation of dry matter, organic matter and production of microbial biomass in vitro in goat. Vet. World, 8(10): 1172-1176.

15. Snedecor, G.W. and Cochran, W.G. (1994) Statistical Methods. $8^{\text {th }}$ ed. Affiliated East-West Spress Pvt. Ltd., New Delhi.

16. Rajamma, K., Kumar, D.S., Rao, E.R. and Nath, D.N. (2015) In vitro evaluation of total mixed ration containing different roughage-concentrate ratios supplemented with or within fibrolytic enzymes. Anim. Sci. Report., 9(2): 63-69.
17. Issac, Y.M., Valli, C. and Balakrishnan, V. (2011) Enhancing utilization of sorghum stover and groundnut haulm by pre treating them with non-starch polysaccharidase mixture. Tamilnadu J. Vet. Anim. Sci., 7(3): 150-153.

18. Gemeda, B.S., Hassen, A. and Odongo, N.E. (2014) Effect of fibrolytic enzyme products at different levels on in vitro ruminal fermentation of low quality feeds and total mixed ration. J. Anim. Plant Sci., 24(5): 1293-1302.

19. Bhasker, T.V., Nagalakshmi, D. and Rao, D.S. (2012) Exogenous fibrolytic enzyme cocktail for improvement of nutrient utilization from sorghum stover in cattle. Indian $J$. Dairy Sci., 65(4): 325-328.

20. Faramarzi-Garmroodi, A., Mesgaran, M.D., Parand, E. and Vakili, A.R. (2013) In vitro effect of increasing levels of Natuzyme ${ }^{\circledR}$ on fermentation responses of corn silage based diet. Annu. Rev. Res. Biol., 3(4): 1066-1073.

21. Elghandour, M.M.Y., Salem, A.Z.M., GonzalezRonquillo, M., Bórquez, J.L., Gado, H.M., Odongo, N.E. and Penuelas, C.G. (2013) Effects of exogenous enzymes on in vitro gas production kinetics and ruminal fermentation of four fibrous feeds. Anim. Feed Sci. Technol., 179: 46-53.

22. Holtshausen, L., Chung, Y.H., Gerardo-Cuervo, H., Oba, M. and Beauchemin, K.A. (2011) Improved milk production efficiency in early lactation dairy cattle with dietary addition of a developmental fibrolytic enzyme additive. J. Dairy Sci., 94: 899-907.

23. Dey, A., Paul, S.S., Pandey, P. and Rathore, R. (2014) Influence of addition of fibrolytic bacterial culture on in vitro degradability of wheat straw, methanogenesis and fermentation metabolites in buffalo. Indian J. Anim. Nutr., 31(3): 223-226.

24. Sipai, S.H., Dutta, K.S., Savsani, H.H., Murthy, K.S., Vataliya, P.H., Chavda, J.A. and Gajera, A.P. (2013) Inclusion of different exogenous fibrolytic enzymes to dry jowar fodder and their effect on in vitro total gas production. Vet. World, 6(11): 839-843.

25. Elghandour, M.M.Y., Kholif, A.E., Hernández, J., Mariezcurrena, M.D., López, S., Camacho, L.M., Márquez, O. and Salem, A.Z.M. (2016) Influence of the addition of exogenous xylanase with or without pre-incubation on the in vitro ruminal fermentation of three fibrous feeds. Czech J. Anim. Sci., 61(6): 262-272.

26. Thirumalesh, T. and Krishnamoorthy, U. (2013) Rumen microbial biomass synthesis and its importance in ruminant production. Int. J. Livest. Res., 3(2): 5-26.

27. Blair, R. (2011) Ingredients for Organic Diets: In Nutrition and Feeding of Organic Cattle. CAB International, Oxfordshire, UK. p135.

28. Azzaz, H.H., Murad, H.A., Kholif, A.M., Morsy, T.A., Mansour, A.M. and El-Sayed, H.M. (2013) Increasing nutrients bioavailability by using fibrolytic enzymes in dairy buffaloes feeding. J. Biosci., 13: 234-241.

29. Morgavi, D.P., Beauchemin, K.A., Nsereko, V.L. and Rode, L.M. (2000) Synergy between ruminal fibrolytic enzymes and enzymes from Trichoderma longibrachiatum in degrading fibre substrates. J. Dairy Sci., 83: 1310-1321.

30. Yang, W.Z., Beauchemin, K.A. and Rode, L.M. (1999) Effects of an enzyme feed additive on extent of digestion and milk production of lactating dairy cows. J. Dairy Sci., 82: 391-403.

31. Nsereko, V.L., Beauchemin, K.A., Morgavi, D.P., Rode, L.M., Furtado, A.F., McAllister, T.A., Iwassa, A.D., Yang, W.Z. and Wang, Y. (2002) Effect of fibrolytic enzyme preparation from Trichoderma longibrachiatum on the rumen microbial population of dairy cows. Can. J. Microbiol., 48: 14-20. 